\title{
THERMAL ENERGY MANAGEMENT OF BLAST FURNACE PLANT
}

\author{
D.Satyagovindamma ${ }^{1}$, D.Azad ${ }^{2}$ \\ ${ }^{I}$ M.Tech Student in Thermal Engineering, Mechanical Engineering, Aditya Institute of technology and management, \\ Andhra pradesh, India \\ ${ }^{2}$ Professor, Mechanical Engineering, Aditya Institute of technology and management, Andhra Pradesh, India
}

\begin{abstract}
The Blast Furnace is a type of metallurgical furnace used for smelting to produce industrial metals, generally iron, but also others such as lead or copper. The product is a liquid pig iron which is suitable for subsequent refining to steel. The raw materials used in the blast furnace are coke, iron ore, sinter, additives and air. Then final products of the blast furnace is molten pig iron, slag and top gas. The main product of the blast furnace is molten pig iron and by products are slag and top gas. During the process of formation of molten metal, $\mathrm{CaO}$ is chemically reacted with $\mathrm{SiO}_{2}$ and from the slag, this slag is send to slag granulation plant. During the above process some gasses are liberated and these gasses are $\mathrm{N}_{2}, \mathrm{CO}, \mathrm{CO}_{2}, \mathrm{H}_{2}$ and $\mathrm{H}_{2} \mathrm{O}$ these are all top gasses, it contains high temperature nearly $200^{\circ} \mathrm{C}$. The main aim of this project is to calculate the mass of coke required in the blast furnace using heat balance. To perform the energy balance in the blast furnace one must identify the heat inputs and outputs based on the processes and reactions taken place in the furnace. Then the parameters in the equations are known quantities except the mass coke.
\end{abstract}

Keywords: Blast furnace, mass of coke, heat inputs, heat outputs, molten pig iron.

\section{INTRODUCTION}

The blast furnace is a tall, vertical furnace which employs carbon, mainly in the form of coke to reduce iron from its oxide ores. The product is a liquid pig iron, which is suitable for subsequent refining to steel. Heat balance calculations of the blast furnace can be characterized by two factors. Temperature is an important characteristic of the thermal performance of furnace. Temperature inside the furnace mainly depends on

[1] The quantity of fuel burning.

[2] The nature of heat absorption of a given furnace.

Another factor on which furnace operation depends is coefficient of heat utilization. At higher values of coefficient of heat utilization, the furnace operates better. The coefficient of heat utilization can be increased by the following two methods.

[1] Heating up the fuel and air before entering into furnace.

[2] Lowering the temperature of waste gasses.

Presently in VISAKHAPATANAM STEEL PLANT the quantity fed to the furnace is decided from past experience and the quality of coal. This project deals with the calculation of coke quantity charged to the furnace by heat balance method.

\section{DEPARTMENTS OF BLAST FURNACE}

To calculate the quantity of coke to be fed to the furnace one must have the knowledge about various sections in the blast furnace department of steel plant and the working principals of those sections.

\subsection{Burden Handling Section}

It is mainly concerned with material handling, like coke and iron bearing materials which are the main raw material for the blast furnace. In the burden handling section there are 17 bunkers to handle these coke and raw materials. Each bunker having the same capacity $950 \mathrm{~m}^{3}$.

\subsection{Furnace}

It is used to produce iron from its oxide ores. Useful volume of furnace is $3200 \mathrm{~m}^{3}$ and it is capable of producing 1.7 mega tones of hot metal per year.

\subsection{Hot Blast Stoves}

Hot blast stoves are four stoves for each furnace. Hot blast stove apparatus for preheating air blown into a blast furnace, an important step in raising the efficiency of iron processing. The stove is a tall cylindrical steel shell with a height of $52 \mathrm{~m}$ and a diameter of $9 \mathrm{~m}$.

\subsection{Slag Granulation Plant}

It is used for producing slag granule by molten slag produced by the furnace is fed to cast house slag granulation plants. Two granulation plants are provided for each furnace adjoining the cast houses on two opposite sides. Today, blast furnace slag is a saleable product rather than a difficult and costly waste material.

For the required calculations one should also know the raw materials, products of the blast furnace and the consumption of those materials. The raw materials are:

[1] Iron ore contains the iron. 
[2] The coke is almost pure carbon. This is for reducing the iron oxide to iron metal.

[3] The limestone takes away impurities in the form of slag.

For the calculation of coke quantity to require in blast furnace we should also know about the furnace operations: Coking coal is heated in the coke ovens to produce coke, while iron ore fines, limestone, dolomite and coke are heated in the sinter plant to produce sinter, which is the major input for the blast furnaces. Afterwards, the coke, sinter and sized iron ore are charged in the blast furnace, with the coke acting as a main fuel and reducing agent for the smelting of the iron. The process converts the iron ore into liquid form, and it is then transported to the LD converters to make steel.

\section{ENERGY BALANCE IN BLAST FURNACE}

\subsection{Heat Inputs}

\subsubsection{Chemical Heat of Fuel Combustion}

Un burnt carbon is gasified into both $\mathrm{CO}$ and $\mathrm{CO}_{2}$ gas. Then the heat generated due to carbon gasification is the sum of heats generated during the gasification of carbon to $\mathrm{CO}$ and the gasification of carbon to $\mathrm{CO}_{2}$.

Heat generated due to gasification of carbon to $\mathrm{CO}=$ $\left(\% \mathrm{C} * \mathrm{M}-\mathrm{C}_{\mathrm{HF}}\right) * \mathrm{X} /(\mathrm{X}+\mathrm{Y}) * \mathrm{CV}_{1}$

Where $\mathrm{CV}_{1}=$ Calorific value of $\mathrm{CO}$ gas

Heat generated due to gasification of carbon to $\mathrm{CO}_{2}=$ $\left(\% \mathrm{C} * \mathrm{M}-\mathrm{C}_{\mathrm{HF}}\right) * \mathrm{Y} /(\mathrm{X}+\mathrm{Y}) * \mathrm{CV}_{2}$

Where $\mathrm{CV}_{2}=$ Calorific value of $\mathrm{CO}_{2}$ gas

Now the total heat generated due to gasification of carbon $=\left(\% \mathrm{C} * \mathrm{M}-\mathrm{C}_{\mathrm{HF}}\right) /(\mathrm{X}+\mathrm{Y}) *\left[\mathrm{X}^{*} \mathrm{CV}_{1}+\mathrm{Y} * \mathrm{CV}_{2}\right]$

\subsubsection{Physical Heat of Preheated Air}

Physical heat of preheated air is the heat due to hot blast. Hot blast consists of air as well as steam.

$$
\mathrm{h}_{\mathrm{b}}=\mathrm{m}_{\mathrm{b}} * \mathrm{C}_{\mathrm{pb}} * \mathrm{t}_{\mathrm{b}}=\mathrm{ma}^{*} \mathrm{C}_{\mathrm{pa}} * \mathrm{t}_{\mathrm{a}}+\mathrm{m}_{\mathrm{st}} * \mathrm{C}_{\mathrm{pst}} * \mathrm{t}_{\mathrm{st}}
$$

\subsubsection{Heat from Oxidation of $\mathrm{H}_{2}$ to $\mathrm{H}_{2} \mathrm{O}$}

During the process the hydrogen gas oxidizes and forms $\mathrm{H}_{2} \mathrm{O}$. Therefore the heat generated due to the oxidation of hydrogen is given by

$$
\mathrm{h}_{\mathrm{o}}=\mathrm{q}^{*} \mathrm{~m}_{\mathrm{b}}
$$

\subsubsection{Heat Formation of Slag}

During the process of formation of hot metal, $\mathrm{CaO}$ is chemically reacted with $\mathrm{SiO}_{2}$ and gives the slag. During this slag formation process some amount of released and is given by:

$$
\mathrm{h}_{\mathrm{sl}}=\mathrm{m}_{\mathrm{sl}} * \mathrm{q}_{1}=\mathrm{m}_{\mathrm{sl}} * \% \mathrm{SiO}_{2} * \mathrm{q}_{1}
$$

\subsection{Heat Outputs}

\subsubsection{Heat Utilized for the Reduction of Oxides}

There are four types of oxides in the burden materials. Those are $\mathrm{Fe}_{2} \mathrm{O}_{3}, \mathrm{FeO}, \mathrm{SiO}_{2}$ and $\mathrm{MnO}$.

$$
\begin{aligned}
& 3 \mathrm{Fe}_{2} \mathrm{O}_{3}+\mathrm{CO} \rightarrow 2 \mathrm{Fe}_{3} \mathrm{O}_{4}+\mathrm{CO}_{2}-1777 \mathrm{~K} . c a l \\
& \mathrm{FeO}+\mathrm{CO} \rightarrow \mathrm{Fe}+\mathrm{CO}_{2}-1151 \mathrm{~K} . \mathrm{cal} \\
& \mathrm{SiO}_{2}+2 \mathrm{CO} \rightarrow \mathrm{Si}+2 \mathrm{CO}_{2}-7160 \mathrm{~K} . \mathrm{cal} \\
& \mathrm{MnO}+\mathrm{CO} \rightarrow \mathrm{Mn}+\mathrm{CO}_{2}-1757 \mathrm{~K} . \mathrm{cal}
\end{aligned}
$$

If the reduction of oxides requires $\mathrm{Q}_{\mathrm{A}}, \mathrm{Q}_{\mathrm{B}}, \mathrm{Q}_{\mathrm{C}}, \mathrm{Q}_{\mathrm{D}}$ amounts of heat then the total heat required for the reduction of oxides is given by:

$$
\mathrm{h}_{\mathrm{X}}=\mathrm{m}_{1} * \mathrm{Q}_{\mathrm{A}}+\mathrm{m}_{2} * \mathrm{Q}_{\mathrm{B}}+\mathrm{m}_{3} * \mathrm{Q}_{\mathrm{C}}+\mathrm{m}_{4} * \mathrm{Q}_{\mathrm{D}}
$$

\subsubsection{Heat in Top Gas}

around $200^{\circ} \mathrm{C}$. top gas basically contains five elements i.e. $\mathrm{N}_{2}, \mathrm{CO}, \mathrm{CO}_{2}, \mathrm{H}_{2}$ and $\mathrm{H}_{2} \mathrm{O}$. Now the heat carried away by flue gasses is calculated according to the first law of thermodynamics as

Heat carried away by Nitrogen $=\mathrm{m}_{\mathrm{N} 2} * \mathrm{Cp}_{\mathrm{N} 2} * \mathrm{t}$

Heat carried away by Carbon monoxide $\quad=\mathrm{m}_{\mathrm{CO}} * \mathrm{C} \mathrm{p}_{\mathrm{CO}} * \mathrm{t}$

Heat carried away by Carbon dioxide $\quad=\mathrm{m}_{\mathrm{co} 2} * \mathrm{Cp}_{\mathrm{co} 2} * \mathrm{t}$

Heat carried away by Water vapours $\quad=\mathrm{m}_{\mathrm{H} 2 \mathrm{O}} * \mathrm{Cp}_{\mathrm{H} 2 \mathrm{O}} * \mathrm{t}$

Heat carried away by Hydrogen $=\mathrm{m}_{\mathrm{H} 2} * \mathrm{Cp}_{\mathrm{H} 2} * \mathrm{t}$

Total heat carried away by top gas, $\mathrm{h}_{\mathrm{t}} \quad=\mathrm{m}_{\mathrm{N} 2} * \mathrm{Cp}_{\mathrm{N} 2} * \mathrm{t}$ $+\mathrm{m}_{\mathrm{CO}} * \mathrm{Cp}_{\mathrm{CO}} * \mathrm{t}+\mathrm{m}_{\mathrm{CO} 2} * \mathrm{Co}_{\mathrm{CO} 2} * \mathrm{t}+\mathrm{m}_{\mathrm{H} 2 \mathrm{O}} * \mathrm{Cp}_{\mathrm{H} 2 \mathrm{O}} * \mathrm{t}+$ $\mathrm{m}_{\mathrm{H} 2} * \mathrm{Cp}_{\mathrm{H} 2} * \mathrm{t}$

\subsubsection{Sensible Heat in Hot Metal}

Molten metal from the blast furnace in the form of liquid is flows into the ladles. This molten metal, which at high temperature, carries some quantity of heat. This heat is called as sensible heat of hot metal.

Sensible heat in hot metal

$$
\mathrm{h}_{\mathrm{m}}=\mathrm{m}_{\mathrm{m}} *\left\{230+\left(\mathrm{t}_{\mathrm{m}}-1100\right) * 0.15\right\}
$$

\subsubsection{Sensible Heat in Slag}

During the process of iron making slag is formed on the top of the molten metal. This slag carries some heat. That is given by:

$$
\mathrm{h}_{\mathrm{s}}=\mathrm{m}_{\mathrm{s}} *\left\{450+\left(\mathrm{t}_{\mathrm{s}}-1400\right) * 0.30\right\}
$$




\subsubsection{Heat Absorbed to Decompose the Steam}

The steam which is mixed with hot air to humidify the air is decompose during the process of iron making. This an endothermic process and it requires some amount of heat.

$$
\mathrm{h}_{\mathrm{st}}=\mathrm{m}_{\mathrm{st}} * \mathrm{q}
$$

\subsubsection{Heat Lost to Cooling Water}

Bottom part of blast furnace is water cooled to maintain the temperature of molten metal at the require value.

$$
\mathrm{h}_{\mathrm{w}}=\mathrm{m}_{\mathrm{cw}} * \mathrm{Cp} *\left(\mathrm{t}_{\mathrm{out}}-\mathrm{t}_{\mathrm{in}}\right)
$$

\subsubsection{Heat Absorbed to Evaporate the Moisture in}

\section{Coke}

Coke and iron bearing a material contains some water as moisture before supply them to the blast furnace. This moisture is evaporated in the blast furnace and it consumes some amount of heat and is given by:

$$
\mathrm{h}_{\mathrm{e}}=\mathrm{m}_{\mathrm{w}} * \mathrm{q}_{\mathrm{w}}
$$

\subsubsection{Unaccounted Losses:}

Heat is radiated from the doors of the furnace. Similarly some amount of heat is accumulated in the lining of the furnace. The total heat consumed and is given by:

$$
\mathrm{h}_{\mathrm{u}}=(0.04 \text { to } 0.05)^{*}\left(\mathrm{~h}_{\mathrm{x}}+\mathrm{h}_{\mathrm{t}}+\mathrm{h}_{\mathrm{m}}+\mathrm{h}_{\mathrm{s}}+\mathrm{h}_{\mathrm{st}}+\mathrm{h}_{\mathrm{w}}+\mathrm{h}_{\mathrm{e}}\right)
$$

Total heat inputs are

$$
\mathrm{h}_{\text {in }}=\mathrm{h}_{\mathrm{f}}+\mathrm{h}_{\mathrm{b}}+\mathrm{h}_{\mathrm{o}}+\mathrm{h}_{\mathrm{sl}}
$$

Total heat outputs are

$$
\begin{aligned}
h_{\text {out }}= & \left(h_{\mathrm{x}}+\mathrm{h}_{\mathrm{t}}+\mathrm{h}_{\mathrm{m}}+\mathrm{h}_{\mathrm{s}}+\mathrm{h}_{\mathrm{st}}+\mathrm{h}_{\mathrm{w}}+\mathrm{h}_{\mathrm{e}}\right)+(0.04 \text { to } 0.05) *\left(\mathrm{~h}_{\mathrm{x}}+\mathrm{h}_{\mathrm{t}}\right. \\
& \left.+\mathrm{h}_{\mathrm{m}}+\mathrm{h}_{\mathrm{s}}+\mathrm{h}_{\mathrm{st}}+\mathrm{h}_{\mathrm{w}}+\mathrm{h}_{\mathrm{e}}\right)
\end{aligned}
$$

\section{PROGRAM}

\#include<stdio.h>

\#include $<$ math.h $>$

\#include $<$ conio $>\mathrm{h}>$

Void main()

\{

float $\mathrm{C}_{\mathrm{p}}, \mathrm{C}_{\mathrm{pa}}, \mathrm{C}_{\mathrm{pst}}, \mathrm{C}_{\mathrm{p}} \mathrm{N}_{2}, \mathrm{C}_{\mathrm{p}} \mathrm{CO}, \mathrm{C}_{\mathrm{p}} \mathrm{CO} 2, \mathrm{C}_{\mathrm{p}} \mathrm{H}_{2}, \mathrm{CpH}_{2} \mathrm{O}$; //declaration of variables related to specific heats

float $\mathrm{T}_{\mathrm{a}} \mathrm{T}_{\mathrm{m}}, \mathrm{T}_{\mathrm{sl}}, \mathrm{T}_{\mathrm{st}}, \mathrm{T}, \mathrm{T}_{\mathrm{co}}, \mathrm{T}_{\mathrm{ci}}$ //declaration of variables related to temperature

floatq,ql,qsl,qa,qb,qc,qd,qw,q5,ho,hsl,hx,ht,hm,hs,hst,hw,hu ,hb,hnet,he; //declaration of variables related to heat floatm,ma,msl,mh,ml,m2,m3,m4,mf,mN2,mCO,mCO2,mH

$2, \mathrm{mH} 2 \mathrm{O}, \mathrm{mm}, \mathrm{mcw}, \mathrm{mst}, \mathrm{mo}$; //declaration of variables related to mass float Cv1,Cv2,c,x,Chf ,a,b,r1,r2,c1,c2,pSio2; // /*declaration of variables*/

clrscr();

printf("enter the percentage of carbon in cokeln");

scanf(“\%f", \&C);

printf("enter the quantity of $\mathrm{CO}$ produced due to gasification $\backslash n$ "); scanf(“\%f”, \&x);

printf("enter the calorific value of $\mathrm{CO}$ and $\mathrm{CO} 2 \backslash \mathrm{n}$ "); scanf(“\%f\% f”, \&Cv1,\&Cv2);

printf("enter the mass of fuel dust $\backslash n$ "); scanf(“\%f",\&mf);

printf("enter the percentage of $\mathrm{C}$ in flue dust and hot metalln");

scanf(“\%f\%f”,c1,\&c2");

/*Chf-mass of carbon in hot metal and flue dust*/

$\mathrm{Chf}=(1000 * \mathrm{c} 2+\mathrm{mf} * \mathrm{c} 1) / 100$;

Printf("enter the mass and the temperature of air $\backslash n ")$; scanf(“\%f\%f,\&ma,\&Ta);

/*Cpa-specific heat of air*/

$\mathrm{Cpa}=\left(0.25 \mathrm{f}+0.173 \mathrm{f}^{*}\right.$ pow $\left.(10,-4) * \mathrm{Ta}\right)$;

printf("enter the mass of slag $\backslash n$ ");

scanf(“\%f”,\&ms1);

$\mathrm{q} 1=0.42 ; / * \mathrm{q} 1$-heat of caOsio $2 / \mathrm{kg}$ of Sio $2 * /$

printf("enter mass of Hydrogen utilized $\backslash n$ ”);

scanf(“\%f”, \&mh);

printf("enter the mass of Fe2o3,Feo,Sio2 and Mnoln");

scanf(“\%f\%f\%f\%f”, \&m1,\&m2,\&m3,\&m4);

$\mathrm{qa}=1.777 \mathrm{f} ; / *^{*}$ qa-heatconsumed during reduction ofFe2o3 to Feln*/

$\mathrm{qb}=1.151 ; / * \mathrm{qb}-\mathrm{heat}$ consumed during reduction of Feo to $\mathrm{Fe}^{*} /$

$\mathrm{qc}=7.160 \mathrm{f} ;{ }^{*} \mathrm{qc}-\mathrm{heat}$ consumed during reduction of sio2 to si*/

$\mathrm{qd}=1.175 \mathrm{f} ; / * \mathrm{qd}-\mathrm{heat}$ consumed during reduction of Mno to $\mathrm{Mn} * 1$

printf("enter mass of Nitrogen, Carbonmonoxide, Carbondioxide, Hydrogen and Watervapour $\backslash n$ ");

scanf(“\%f\%f\%f\%f\%f”,\&mN2,\&mCO,\&mCO2,\&mH2,\&m $\mathrm{H} 2 \mathrm{o})$;

printf(“enter the mass and temperature of molten metalln"); scanf(“\%of\%f”,\&mm,\&Tm);

printf("enter the temperature of slag and steam $\backslash n$ ");

scanf(“\%f\%f",\&Tsl,\&Tst);

printf("enter the mass of steam which is mixed in the hot blast $\backslash n$ ");

scanf(“\%f”,\&mst);

/*Cpst-specific heat of steam*/

Cpst $=\left(0.436 f+0.62 f^{*}\right.$ pow $\left.(10,-4) * T s t\right)$;

printf("enter the percentage of $\mathrm{H} 2 \mathrm{O}$ in coke and iron oreln");

scanf(“\%f\%f",\&a,\&b);

/*qw-heat required for evaporation of $\mathrm{H} 2 \mathrm{O}$ in iron ore*/ $\mathrm{qw}=0.586 \mathrm{f}$;

printf("enter the mass of iron ore and mass of the cooling water $\lfloor n ")$;

scanf(“\%f\% f”,\&mo,\&mcw);

$\mathrm{Cp}=0.998 ; / / \mathrm{Cp}$-specific heat of water $=0.998 \mathrm{f}$

printf("enter the temperature of cooling water at outlet and inlet $\backslash n$ "); 
scanf(“\%f\%f”,\&Tco,\&Tci);

printf("enter the temperature of top gas $\backslash n$ ");

scanf(“\%f",\&T);

/*CpN2-specific heat of Nitrogen*/

$\mathrm{CpN} 2=(0.241 \mathrm{f}+0.18 \mathrm{f} * \operatorname{pow}(10,-4) * \mathrm{~T})$;

/*CpCO-specific heat of Carbonmonoxide*/

$\mathrm{CpCO}=(0.242 \mathrm{f}+0.18 \mathrm{f} *$ pow $(10,-4) * \mathrm{~T})$;

/*CpCO2-specific heat of Carbondioxide*/

$\mathrm{CpCO} 2=(0.205 \mathrm{f}+0.18 \mathrm{f} * \operatorname{pow}(10,-4) * \mathrm{~T})$;

/*CpH2-specific heat of Hydrogen*/

$\mathrm{CpH} 2=(3.35 \mathrm{f}+0.22 \mathrm{f} * \operatorname{pow}(10,-4) * \mathrm{~T})$;

$/ * \mathrm{CpH} 2 \mathrm{O}$-specific heat of Water vapour*/

$\mathrm{CpH} 2 \mathrm{O}=(0.463 \mathrm{f}+0.62 \mathrm{f} * \operatorname{pow}(10,-4) * \mathrm{~T})$;

q5=3.21f;//q5-heat of formation of water vapour

$\mathrm{q}=28.676 \mathrm{f} ; / / \mathrm{q}$-heat required for oxidation of $1 \mathrm{Kg}$ of $\mathrm{H} 2$

$\mathrm{hb}=\left(\mathrm{ma}^{*} \mathrm{Cpa} * \mathrm{Ta}+\mathrm{mst}^{*}{ }^{*}\right.$ pst $\left.* \mathrm{Tst}\right) / 1000$;

ho $=\mathrm{q}^{*} \mathrm{mh}$;

printf("enter the percentage of $\mathrm{SiO} 2 \backslash \mathrm{n}$ ");

scanf(“\%f",\&pSiO2);

$\mathrm{hsl}=\mathrm{msl} * \mathrm{pSiO} 2 * \mathrm{q} 1 / 100$;

$\mathrm{hx}=\mathrm{ml} * \mathrm{qa}+\mathrm{m} 2 * \mathrm{qb}+\mathrm{m} 3 * \mathrm{qc}+\mathrm{m} 4 * \mathrm{qd}$

$\mathrm{ht}=(\mathrm{mN} 2 * \mathrm{CpN} 2+\mathrm{mCO} * \mathrm{CpCO}+\mathrm{mCO} 2 * \mathrm{CpCO} 2+$

$\mathrm{mH} 2 * \mathrm{CpH} 2+\mathrm{mH} 2 \mathrm{O} * \mathrm{CpH} 2 \mathrm{O}) * \mathrm{~T} / 1000$;

$\mathrm{hm}=(\mathrm{mm} *(230+(\mathrm{Tm}-1100) * 0.15)) / 1000$;

$\mathrm{hs}=\left(\mathrm{msl}^{*}(450+(\mathrm{Tsl}=1400) * 0.3)\right) / 1000$;

hst $=(\mathrm{mst} * \mathrm{q} 5)$;

$\mathrm{hw}=(\mathrm{mcw} * \mathrm{Cp} *($ Tco-Tci $)) / 1000$;

hnet $=1.04 *($ hx + ht + hm + hs + hst + hw $)-($ hb + ho + hsl $)$;

$\mathrm{r} 1=(\mathrm{x} * \mathrm{Cv} 1 /(\mathrm{x}+1)+(\mathrm{Cv} 2 /(\mathrm{x}+1)))$;

$\mathrm{r} 2=1.04 * \mathrm{qw}$;

$\mathrm{m}=(100 *$ hnet $+(\mathrm{b} * \mathrm{mo} * \mathrm{r} 2)+(100 * \mathrm{Chf} * \mathrm{r} 1)) /((\mathrm{C} * \mathrm{r} 1)-(\mathrm{a} * \mathrm{r} 2))$;

$\operatorname{clrscr}()$;

printf("the resultant mass of the coke is: \% $\%(n$ ", m);

$\operatorname{getch}()$; \}

\section{CONCLUSION}

The main aim of this project is to calculate the mass of the coke in a blast furnace by using heat balance sheet. Heat balance sheet is mainly used to balance the heat inputs which are equal to heat outputs. Generally excess feed of coke results more energy losses and feed deficiency leads to smelting problems. By using the above calculations we can know the exact amount of coke which has to fed into blast furnace for iron making with no losses. A C-program has been developed to calculate the mass of the coke by using 33 known and one unknown parameter.

So this project concludes the exact amount of coke which has to be fed in to blast furnace and C-program helps in calculating the mass of the coke.

\section{REFERENCES}

[1] Gerard Danloyv, Jan van der stel, Peter Schmole.,"Heat and mass balance in the ULCOS Blast Furnace", proceedings of the $4^{\text {th }}$ Ulcos seminar, 1-2 October 2008.
[2] Manmohan Soni, Sankalp Verma,"Thermal Analysis of Blast Furnace Cooling Stave Using CFD", International Journal of Inventive Engineering and Sciences (IJIES) ISSN: 2319-9598, Volume-2, Issue5, April2014.

[3] Gourav Kumar Thakur, Kawal Lal Kurrey, Abhishek Bhushan, Sandeep Kashyap.,"Analysis of Fuel Injection System in Blast Furnace with the Help of CFD Software Approach", International Journal of Scientific and Research Publications, Volume 3, Issue 3, March 2013,1 ISSN 2250-3153. 